\title{
DOKLADY FOTOGRAFICKÉ ČINNOSTI FRANTIŠKA ŘEHOŘE VE SBÍRKÁCH NÁRODNÍHO MUZEA ${ }^{1}$
}

\section{Daniela Záveská - Helena Medřická}

\section{Documents in the National Museum Collections Concerning František Řehoř‘s Photographic Activity}

\begin{abstract}
This text examines the photography collection of František Řehoř, created in the last quarter of the $19^{\text {th }}$ century. The archives consisting of photographs and negatives are just one of the many components of the extensive research and collection activities carried out by the researcher. The collection constitutes a valuable insight into the everyday life of the inhabitants of rural settlements in eastern Galicia. The informative value of the collection is greatly enhanced by the detailed descriptions with which the author has accompanied his photographs.
\end{abstract}

Keywords: František Řehoř - eastern Galicia - historical photography - last quarter of the $19^{\text {th }}$ century

Contact:

Mgr. Daniela Záveská, Etnografické oddělení, Historické muzeum Národního muzea, Letohrádek Kinských 97, 15000 Praha; daniela.zaveska@nm.cz Mgr. Helena Medřická, Etnografické oddělení, Historické muzeum Národního muzea, Letohrádek Kinských 97, 15000 Praha; helena.medricka@nm.cz

Článek se zaměřuje na část fotografické sbírky Františka Řehoře uložené ve fondech Národního muzea. Obsáhlá fotodokumentace je součástí intenzivní sbírkotvorné a badatelské činnosti F. Řehoře v oblasti východní Haliče. Fotografie a negativy, které pořídil, jsou v současnosti rozptýleny do několika sbírkových fondů a dosud nedošlo k jejich celkovému zhodnocení.

František Řehoř (16. 12. 1857 Stěžery - 6. 10.1899 Praha) byl průkopníkem etnografického výzkumu ve východní Haliči. O studium místní lidové kultury se začal zajímat krátce po svém př́ijezdu v roce $1877 .^{2}$ V Haliči Řehoř nepřetržitě pobýval až do roku 1888. I poté se za účelem výzkumu do oblasti opakovaně vracel. ${ }^{3}$

Zásadní vliv pro jeho badatelský růst měla spolupráce $\mathrm{s}$ Českým průmyslovým muzeem, kterou navázal roku 1878. ${ }^{4}$ Pro muzeum vytvořil rozsáhlou sbírku předmětů mapující východohaličskou lidovou kulturu. ${ }^{5}$ Řehoř sice začínal jako samouk, ale vzhledem ke své píli se v průběhu času v podstatě profesionalizoval. Získané zkušenosti a poznatky publikoval v řadě periodik, např́klad ve Světozoru, Slovan- ském sborniku, Lumíru či Zlaté Praze. Je autorem mnoha hesel v Ottově slovniku naučném, do kterého přispíval od konce osmdesátých let. Plně badatelsky vytěžit dlouholeté úsilí mu zabránila předčasná smrt. ${ }^{6}$

Studium fondu fotografií a negativů je součástí dlouhodobého projektu zpracování etnografických sběrů Františka Řehoře. Digitalizace sbírky 336 skleněných negativů usnadnila srovnání s fotografickou sbírkou, která obsahuje 553 pozitivních kopií na papíře. Pro další práci byla sestavena tabulka propojující jednotlivé fondy v rámci Národního muzea, což umožnilo sledovat, jakým způsobem Řehoř při vyvolávání fotografií a přípravě sbírky postupoval. Komparací s fotografickým materiálem v online katalogu Österreichische Nationalbibliothek (dále ÖNb) se také podařilo určit autora série fotografií, které Řehoř do sbírky zakoupil. Kromě obrazové složky byla věnována pozornost textům na zadních stranách fotografií. Článek si neklade za cíl kompletní zpracování fotografického materiálu do všech detailů. Je především úvodem do problematiky a poukazuje na vybrané poznatky, které dosud nebyly publikovány.

Předložená práce vznikla za finanční podpory Ministerstva kultury v rámci institucionálního financování dlouhodobého koncepčního rozvoje výzkumné organizace Národní muzeum (DKRVO 2019-2023/13.I.c, 00023272).

Řehoř se do Haliče přestěhoval krátce po maturitě. Následoval své rodiče, kteří zde začali hospodařit.

3 Nad'a VALÁŠKOVÁ, František Řehoř (1857-1899) a jeho etnografická činnost. (S ukázkami článků F. Řehoře z Haliče), Praha 1999; Petr KALETA, Cesta do Haliče. František Rehoř a poznání života východní Haliče ve druhé polovině 19. století, Olomouc 2004.

4 Nad’a VALÁŠKOVÁ, František Řehoř (1857-1899) a jeho etnografická činnost, s. 26.

5 Řehořova sbírka je dnes součástí fondu Etnografického oddělení Historického muzea Národního Muzea. K tomu více Jiří HORÁK, Příspěvek k dějinám vzájemných vztahů česko-ukrajinských. Dílo Františka Řehoře, Český lid, 1954, roč. 41, č. 6, s. 254-258; Olena FEDORCHUK - Oleh BOLYUK - Jan POHUNEK - Nad'a VALÁŠKOVÁ, Lidová kultura Ukrajinců rakousko-uherské monarchie v etnografické sbírce Františka Řehoře z 80. a 90. let 19. století, Český lid, 2020, roč. 107, s. 71-92.

6 Nad'a VALÁŠKOVÁ, František Řehoř (1857-1899) a jeho etnografická činnost, s. $24,36$. 


\section{Stav bádání}

Jako první se dílem Františka Řehoře v 50. letech intenzivně zabýval Michal Molnár. V témže období o Řehořovi publikoval Jiří Horák. ${ }^{7}$ Zvýšený badatelský zájem o Řehořovu osobnost vyvolalo v závěru 90 . let 20 . století blížící se sté výročí badatelova úmrtí. Těmto aktivitám předcházela publikace The Land they left behind autorů Stelly Hryniuk a Jeffrey Picknického vydaná v roce 1995 v kanadském Torontu. ${ }^{8}$ Zde bylo otištěno 125 Řehořových negativů. Snímky ilustrovaly text věnovaný lidové kultuře východní Haliče, rozčleněný do jedenácti kapitol, které vycházely z témat obsažených na Řehořových snímcích. Kapitoly se věnovaly bydlení, obdělávání půdy, řemeslům, práci žen, trhům, veřejnému životu, významným dnům v průběhu roku. Úvodem publikaci opatřila Nad’a Valášková.

O čtyři roky později připravila Milena Secká CD-ROM, na kterém publikovala kompletní přehled fotografické sbírky

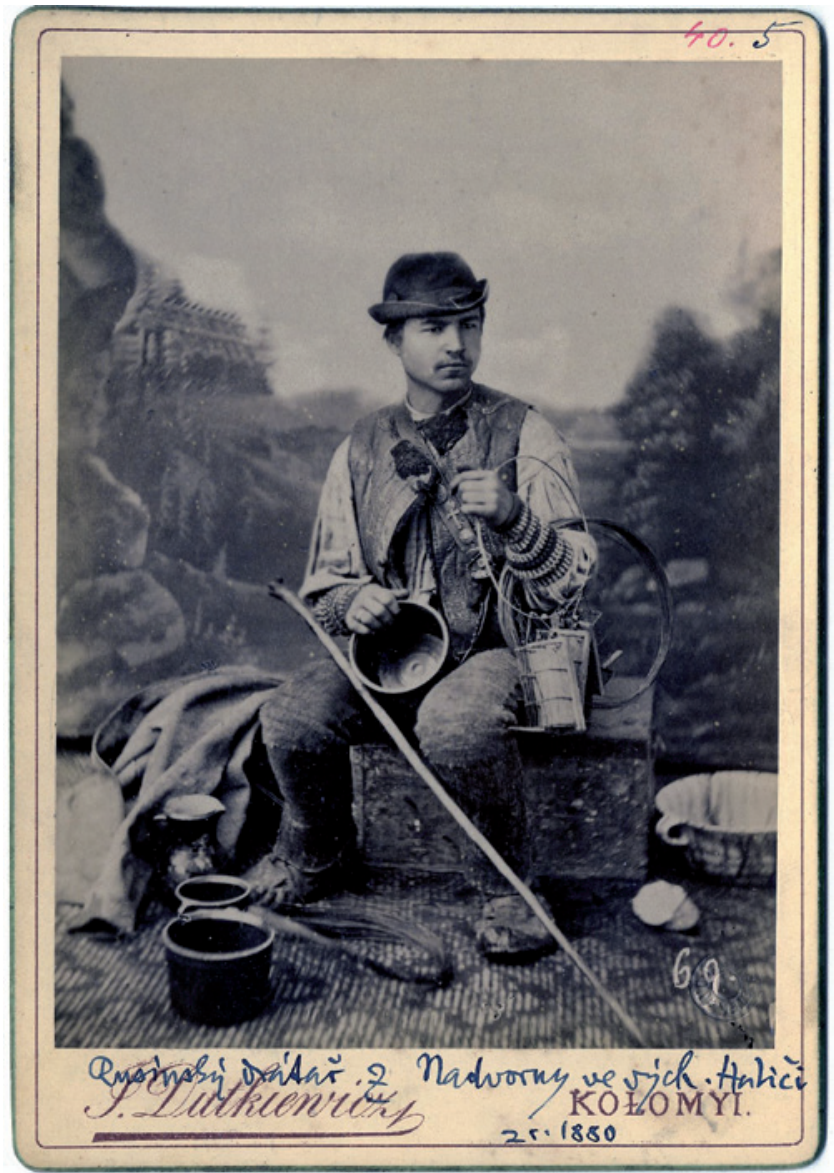

Obr. 1. "Rusínský drátař z Nadvorny ve východní Haliči“, Nadvirna, východní Halič, 1880. Národní muzeum - Náprstkovo muzeum, sbírka historických fotografií, sig. 40.0005. Foto Juliusz Dutkiewicz.

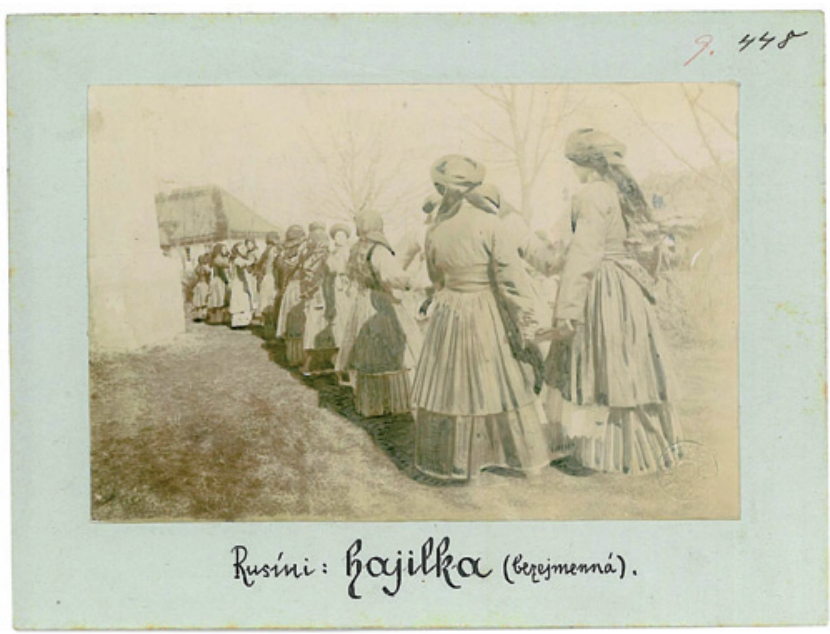

Obr. 2. Př́klad retušované fotografie. „Rusíni: hájilka (bezejmenná)", východní Halič, 90. léta 19. století, NM - NpM, sbírka historických fotografií, sig. 9.0448. Foto František Řehoř.

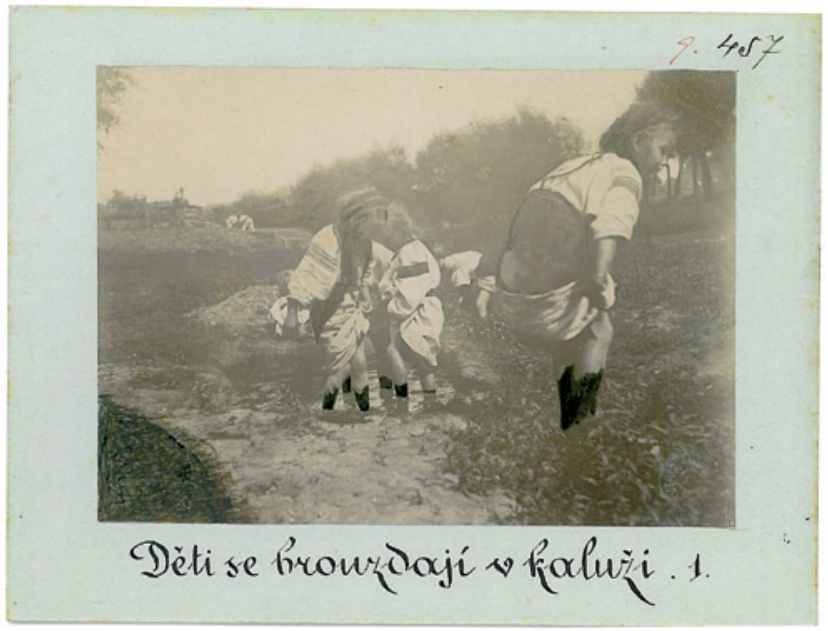

Obr. 3. Příklad retušované fotografie. „Děti se brouzdají v kaluži 1.", Tyškivci, východní Halič, 90. léta 19. století, NM - NpM, sbírka historických fotografií, sig. 9.0457. Foto František Řehoř.

F. Řehoře uložené v Náprstkově muzeu asijských, afrických a amerických kultur. ${ }^{9}$

V monografii zaměřené na etnografickou činnost F. Řehoře se $\mathrm{v}$ jedné $\mathrm{z}$ kratších kapitol věnovala fotografické sbírce Nad'a Valášková, která zde stručně shrnula rozsah Řehořových aktivit na tomto poli. ${ }^{10} \mathrm{~K}$ tématu se $\mathrm{N}$. Valášková krátce vrátila opět $\mathrm{v}$ roce $2007 .^{11}$

Dílem F. Řehoře se dlouhodobě zabýval Petr Kaleta, který je autorem monografie Cesta do Haliče. Fotodokumentační činnosti je věnována jedna z kapitol. Vydání knihy předcházel článek na stejné téma. ${ }^{12}$

\footnotetext{
Např́klad Michal MOLNÁR, Франтішек Ржегорж - великий друг українского народу, Дукля, 195б, № 3, s. 121-146; Jiří HORÁK, Příspěvek k dějinám vzájemných vztahů česko-ukrajinských, s. 254-258.

Stella HRYNIUK - Jeffrey PICKNICKY, The Land they left behind, Toronto 1995.

9 Milena SECKÁ, František Řehoř and his Collection of Photographs from Halič in the Náprstek Museum (on the $100^{\text {th }}$ anniversary of his birth), Annals of the Náprstek Museum, 1999, roč. 20, CD-ROM.

10 Nad’a VALÁŠKOVÁ, František Řehoř (1857-1899) a jeho etnografická činnost, s. 56-58.

11 Nad’a VALÁŠKOVÁ, František Řehoř a jeho fotografická sbírka z Haliče, Ukrajinský žurnál, české vydání, 2007, roč. 2, č. 2, s. 32-34.

12 Petr KALETA, Fotodokumentace a sběratelství v díle Františka Řehoře, Slovenský národopis, 2003, 51, č. 2, s. 235-243; Petr KALETA, Cesta do Haliče, s. 138-144.
} 


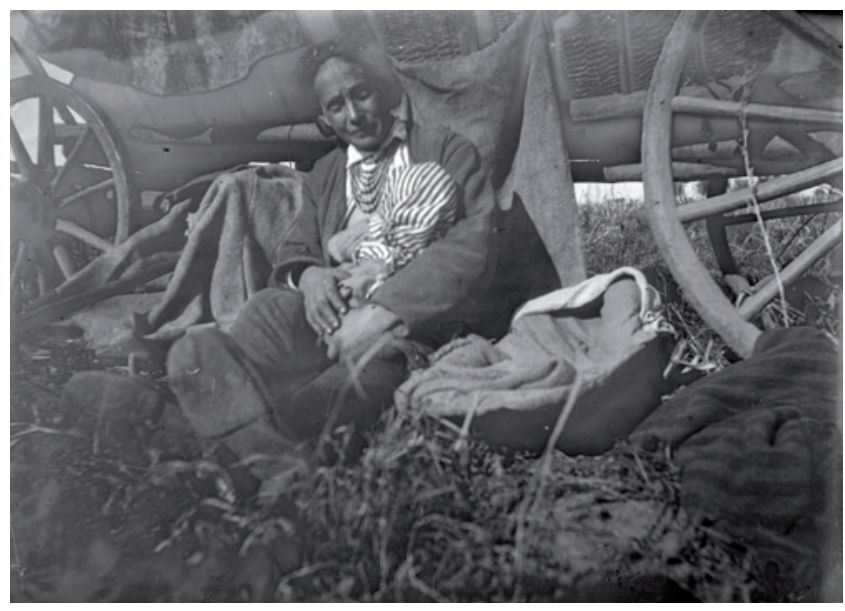

Obr. 4. „Matka na brambořišti kojí", Židačiv, východní Halič, 90. léta 19. století, František Řehoř, Archiv Národního muzea, EAO n XIII_174.

Výběr z Řehořových snímků byl veřejnosti představen jako součást výstavy Stará Ukrajina Františka Řehoře konané v Národopisném muzeu NM v roce 2019. Převážná většina snímků pocházela $\mathrm{z}$ fondu Etnografického obrazového archivu (dále EAO) v Archivu Národního muzea. Několik snímků je rovněž součástí informační brožury, která byla u prŕležitosti výstavy vydána. ${ }^{13}$

\section{Řehořova fotodokumentace a archivní fondy}

Jednotlivé části fotografické sbírky jsou v současnosti rozděleny do fondů Náprstkova muzea (dále NpM), Archivu Národního muzea (dále ANM) a Památníku národního písemnictví (dále PNP). Pravděpodobně se tak stalo vlivem rozdílných okolností, ${ }^{14}$ za jakých byly přijímány do muzea. ${ }^{15}$

Fotografie, jejichž autorem je sám F. Řehoř, ale také snímky získané od místních fotografů, jsou uloženy v NpM. Celkem 137 položek (signatura 40.001-40.0137a) ${ }^{16}$ zakoupil Řehoř od místních fotografů. Autorství je pak Řehořovi připisováno u 553 snímků $^{17}$ (signatura 9.0001-9.0553). ${ }^{18}$

Sbírka negativi̊ je uložena jako součást EAO ANM. Do fondu EAO byly negativy předány roku 1981 z Historicko-archeologického oddělení Historického muzea NM

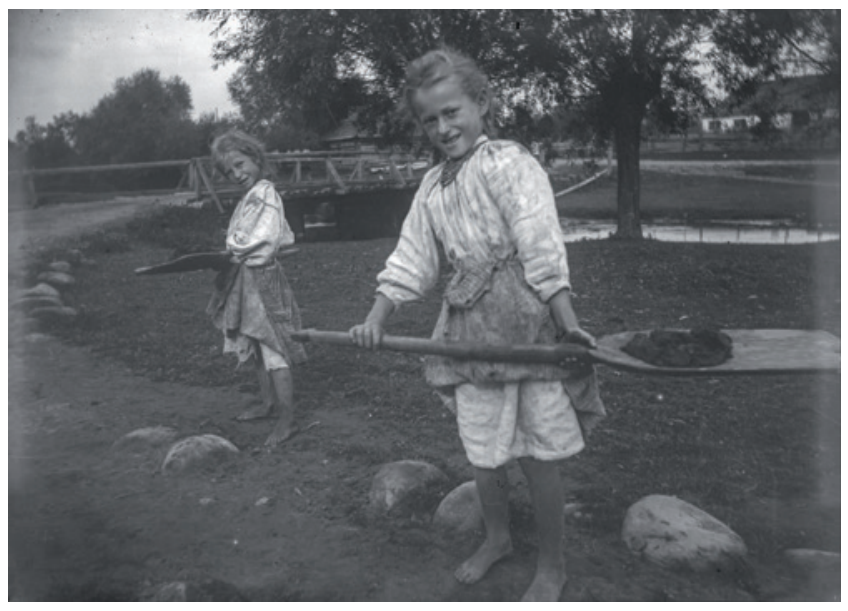

Obr. 5. „Rusínské školačky sbírají trus na návsi“, východní Halič, 90. léta 19. století, ANM, EAO n XXII_290. Foto František Řehoř.

(př. č. 4/1981) v počtu 351 kusů. ${ }^{19}$ Při zpracování bylo nalezeno pouze 343 kusů skleněných desek o rozměrech $9 \times$ $12 \mathrm{~cm}$. Jejich systematické evidenci se v roce 2017 věnoval Roman Tykal, který využil původní dokumentaci F. Řehoře a materiály sestavené Jelenou Látalovou. Současné třídění negativů tak v podstatě vychází ze systematizace F. Řehore, který negativy seřadil dle témat a opatřil popisky. V roce 2019 byly negativy digitalizovány.

Zcela nezpracovaná a neprobádaná zůstává část negativů uložená v PNP. Celkem 13 krabiček obsahuje okolo 170 kusů skleněných desek o rozměru $9 \times 12 \mathrm{~cm} .{ }^{20}$ Dle informací Ivetty Dörflové se dosud nalézají v původních obalech. K pokusu o zpracování fondu došlo na počátku 90. let, záhy však bylo od projektu upuštěno. V PNP je uložen i fragment Řehořových fotografíi (4 ks), které jsou součástí jeho pozůstalosti. ${ }^{21}$

Potřebu porovnat fond fotografií a negativů naznačil v interních materiálech ANM již R. Tykal. Při srovnání Řehořovy fotografické sbírky $\mathrm{v} \mathrm{NpM}$ a negativů EAO v Archivu $\mathrm{NM}^{22}$ se autorkám tohoto článku podařilo $\mathrm{k}$ fotografiím přiřadit 255 negativů. Sbírka negativů obsahuje přes 80 snímků, které nejsou jako pozitivy součástí Řehořovy fotografické sbírky v NpM. Srovnání ukazuje, že množství snímků pořízených Františkem Řehořem je již v tuto chvíli ${ }^{23}$

13 Helena MEDŘICKÁ - Daniela ZÁVESKÁ - Kristýna BLECHOVÁ - Oleh BOLYUK - Olena FEDORCHUK, Stará Ukrajina Františka Řehoře, informační brožura k výstavě, Praha 2019.

14 Osudy jednotlivých částí fondů svázaných $\mathrm{s} \mathrm{F}$. Řehořem budou předmětem dalšího bádání.

15 Digitalizované fotografie jsou veřejnosti zpř́stupněny na portálu Archivní VadeMeCum Národního muzea v sekci Náprstkova muzea asijských, afrických a amerických kultur. Dostupné z: http://vademecum.nm.cz/nm/

16 Podstatnou část fotografí́, jejichž autorství bylo v katalogu připisováno Františku Řehořovi, se podařilo ztotožnit s fotografiemi Juliusze Dutkiewicze, u několika dalších fotografií Dutkiewiczovo autorství naznačuje charakter fotografie. Österreichische Nationalbibliothek (dále ÖNb) [cit. 31.5.2021]. Dostupné z: https://onb.wg.picturemaxx.com

17 Dodejme, že od signatury 9.0503 se snímky od zbytku sbírky liší rozměry, ale také tématem. Zachycují převážně krajinu, případně sídla a budovy. Tato část sbírky rovněž obsahuje jediné čtyři snímky z interiéru. Rozměr fotografie se pohybuje okolo $16 \times 10,5 \mathrm{~cm}$, rozměr kartonu cca $18 \times 13$ cm. Jednu z těchto fotografí je díky publikaci ve Světozoru možné datovat 1894 ante quem. Druhá je pak datována do roku 1894 díky události, kterou zachycuje.

18 Nad’a VALÁŠKOVÁ, František Řehoř (1859-1899) a jeho etnografická činnost, s. 56; Petr KALETA, Cesta do Haliče, s. 140.

19 P. Kaleta zmiňuje 151 dochovaných negativů v EAO, v té době ještě uložených v Etnografickém oddělení Národního muzea. Petr KALETA, Cesta do Haliče, s. 140.

20 Za poskytnutí informací děkujeme Mgr. Ivettě Dörflové

21 Fotografie velikonočních dívčích her nesou signatury $6578,6579,6580,6581$. Jedná se zřejmě o kopie, které nebyly součástí fondu vytvořeného Řehořem pro průmyslové muzeum. Dvě z nich jsou obsaženy ve fondu se signaturou 9 . v NpM. Ke zbývajícím dvěma lze přiřadit negativ z fondu EAO ANM.

${ }_{22}$ Pro srovnání byly využity scany 336 negativů, zbývajících 7 negativů se dosud nachází v restaurátorských dílnách a nebyly zatím digitalizovány.

23 Bez srovnání se sbírkou negativů uložených v PNP. 

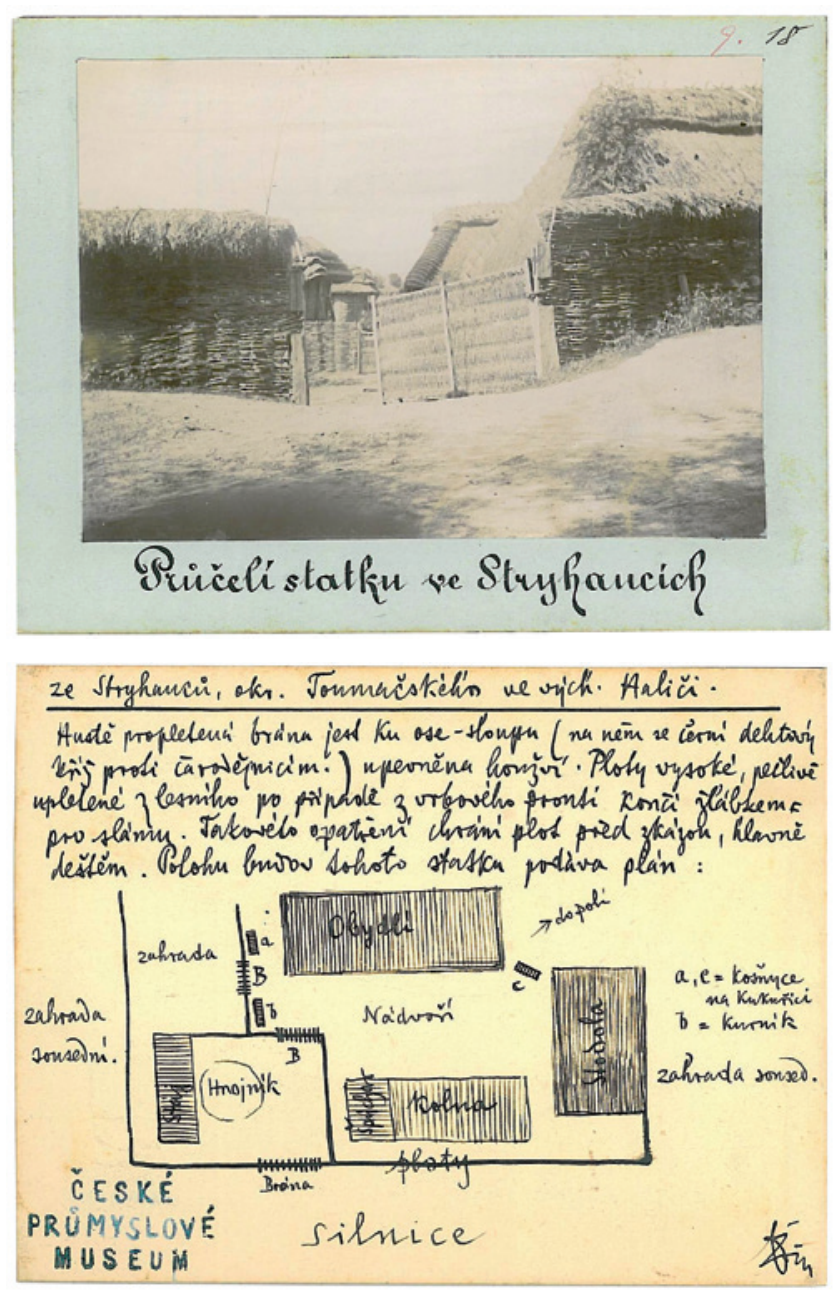

Obr. 6. „Průčelí statku ve Stryhaňcích.“ Zadní strana fotografie se schematickým plánkem, Stryhanci, východní Halič, 90. léta 19. století, NM - NpM sbírka historických fotografií, sig. 9.0018. Foto František Řehoř. o osm desítek záběrů větší, než bylo dosud popsáno v literatuře. ${ }^{24}$ Zároveň nelze vyloučit, že se po zpracování negativů v péči PNP toto číslo ještě navýší.

\section{Řehořova fotografická sbírka a okolnosti jejího formování}

Starší vrstvu v Řehořově kolekci tvoří fotografie zakoupené od místních fotografů. ${ }^{25} \mathrm{~N}$. Valášková v souvislosti s autorstvím zmiňuje fotografy Juliusze Dutkiewicze ${ }^{26}$ a Alfreda Silkiewicze. ${ }^{27} \mathrm{U}$ větší části snímků není uvedeno jméno autora. Od signatury 40.0074 výše nalezneme na kartonech, ${ }^{28}$ na kterých jsou fotografie nalepeny, Řehořův podpis. Není však pravděpodobné, že by takto Řehoř označoval své autorství. U několika signovaných fotografií je dokonce možné Řehoře jako autora na základě existence totožných fotek s Dutkieviczovým logem přímo vyloučit. ${ }^{29}$ Úvahy nad raným obdobím Řehořovy fotografické tvorby $\mathrm{v}$ Haliči v 80. letech, tak jak jej popsal P. Kaleta, ${ }^{30}$ se jeví jako problematické a fotografická sbírka pro ně neposkytuje dostatečnou oporu, ${ }^{31}$ i když ojedinělé aktivity tohoto druhu zatím nelze ani vyloučit.

Snímky jsou dále opatřeny textem, v němž rozpoznáváme Řehořův rukopis. Jedná se o stručné informace upřesňující obsah, lokalitu a dataci. Na většině fotografií, s výjimkou 46 kolorovaných, ${ }^{32}$ je uveden letopočet 1880 . Nabízí se otázka, zda uvedený letopočet odkazuje na datum vzniku fotografií, či pouze na dobu jejich zakoupení. ${ }^{33}$

Převážná část fotografií vykazuje vysokou míru stylizace. Kromě snímků ateliérových obsahuje soubor také záběry z exteriéru. Zachycují jednotlivce, skupiny, muže i ženy $\mathrm{v}$ tradičních oděvech. Nalezneme také fotografie reprezentující různá povolání či společenský status. ${ }^{34}$ Pouze dvě z nich zobrazují konkrétní osobnost. Jedná se o mosazníka Nykołu Dutčaka (40.0006) a řezbáře Jurko Skryblaka ${ }^{35}$ (40.0084). Zahrnuty jsou také žánrové scény ${ }^{36}$ či architektura. Zmíněná témata posléze nalezneme v mnohem větším rozsahu a variantách v Řehořově autorské tvorbě.

Motivací k nákupu fotografií mohla být pro Řehoře potřeba ilustrovat své texty obrazovým materiálem. Snímky

24 Nad’a VALÁŠKOVÁ, František Řehoř (1857-1899) a jeho etnografická činnost, s. 56-58; Petr KALETA, Cesta do Haliče, s. 140.

25 Signatura 40.001-40.0137a.

26 Celkem 26 fotografí ze souboru je opatřeno kartonem s originálním logem ateliéru Juliusze Dutkiewicze. V souboru se zároveň nachází řada fotografí́, jejichž autorství je alespoň dle online databáze obrazového archivu ÖNb připisováno právě J. Dutkiewiczovi. Na základě informací z databáze by bylo možné s Dutkiewiczovou tvorbou ztotožnit dalších 39 snímků, minimálně u 13 neurčených fotografií by pak mohla stejného autora naznačovat kompozice. U 59 fotografií se dosud nepodařilo identitu autora doložit. ÖNb [cit. 31.05.2021]. Dostupné z: https://onb.wg.picturemaxx.com

27 Konkrétní snímky pořízené A. Silkiewiczem se autorkám dosud nepodařilo určit. K tématu: Nad’a VALÁŠKKOVÁ, František Řehoř a jeho fotografická sbírka z Haliče, s. 32.

28 Rozměr kartonů cca $16,5 \times 11,5 \mathrm{~cm}$.

29 V NpM sig. 40.0133 bez originálního kartonu J. Dutkiewicze, v online databázi ve variantě s logem: KWR 20, 55, ÖNb [cit. 31.5.2021]. Dostupné z: https://onb.wg.picturemaxx.com. V archivní databázi Vademecum je uváděn jako autor F. Řehoř, Archivní VadeMeCum NM [cit. 31.5.2021]. Dostupné z: http://vademecum.nm.cz/

30 Petr KALETA, Cesta do Haliče, s. 139.

31 Např́iklad fotografie „Huculští manželé z Berhometa“ (Světozor, 1881, roč. 15, č. 45, s. 542), jejíž autorství P. Kaleta Řehořovi připisuje, je vedena v online databázi ÖNb jako fotografie Dutkiewiczova. Stejně tak fotografie „Huculský dřevař“ (Světozor, 1882, roč. 16, č. 41, s. 481) je Dutkiewiczova. Situace se opakuje i u dalších článků z tohoto období. Napřs. Světozor 1882, roč. 16, č. 7, č. 15 a č. 39 . Pro srovnání v online katalogu pod čísly: Pk 106, 69b; Pk 106, 74a; Pk 106, 88b; Pk 106, 71a; Pk 106, 89b ÖNb [cit. 31.5.2021]. Dostupné z: https://onb.wg.picturemaxx.com

32 Část z fotografí byla F. Řehořem kolorována. K tomu více Petr KALETA, Cesta do Haliče, s. 143-144.

33 Dodejme jen, že zmíněná datace koresponduje s údaji totožných fotografí́ v katalogu ÖNb [cit. 31.05.2021]. Dostupné z: https://onb.wg.picturemaxx.com

34 Drátař, včelař, myslivec, starosta, starostova žena, hudebníci, slepý lyrník s doprovodem, trestanci, žebračka.

35 Ikona vyřezaná J. Skryblakem je součástí Řehořových sbírek v péči Etnografického oddělení HM NM: inv. č. H4-NS-1139.

36 Stohování sena, jízda na pole, dělníci odpočívající při stavbě mostu, lidé shromáždění k tanci. 


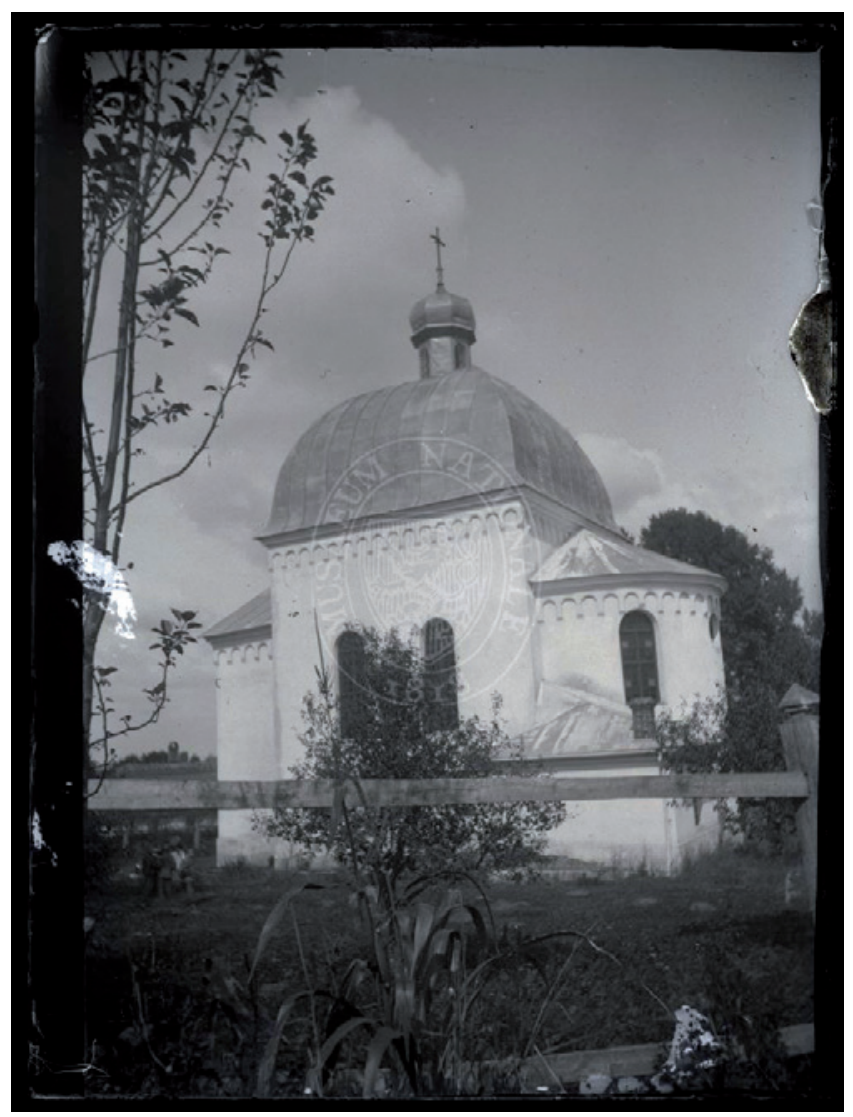

Obr. 7. "Cerkov v Lesienicích (zděná)", Lysynyči, východní Halič, 90. léta 19. století, František Řehoř, Archiv Národního muzea, EAO n XIV_198.

záhy využil v článcích vydaných např́klad ve Světozoru v roce 1881 a $1882 .{ }^{37}$ Publikovány nebyly prrímo zakoupené fotografie, ale kresby dle nich vytvořené. ${ }^{38}$ Nabízí se také úvaha nad snahou zachytit $\mathrm{z}$ hlediska konzervace a skladování problematické části hmotné kultury, jakou byl oděv. ${ }^{39}$ Zároveň je pravděpodobné, že si Řehoř, který opakovaně prokazuje snahu o co možná nejkomplexnější zmapování situace, již v této době uvědomoval význam obrazové dokumentace.

Hlavní část dosud zmapované Řehořovy fotografické sbírky pochází z pozdějšího období. N. Valášková datuje jádro souboru mezi roky 1891 a $1893 .{ }^{40} \mathrm{~V}$ této části sbírky již Řehoř nevystupuje pouze jako sběratel, ale jako etnograf a fotodokumentarista.

Období Řehořovy aktivní fotodokumentační činnosti částečně poodhaluje dopis z 24. září 1892 adresovaný Josefě Náprstkové. Dozvídáme se z něj mnohé o způsobu, jakým se Řehoř chystal sbírku fotografií sestavit. Množství požadova-

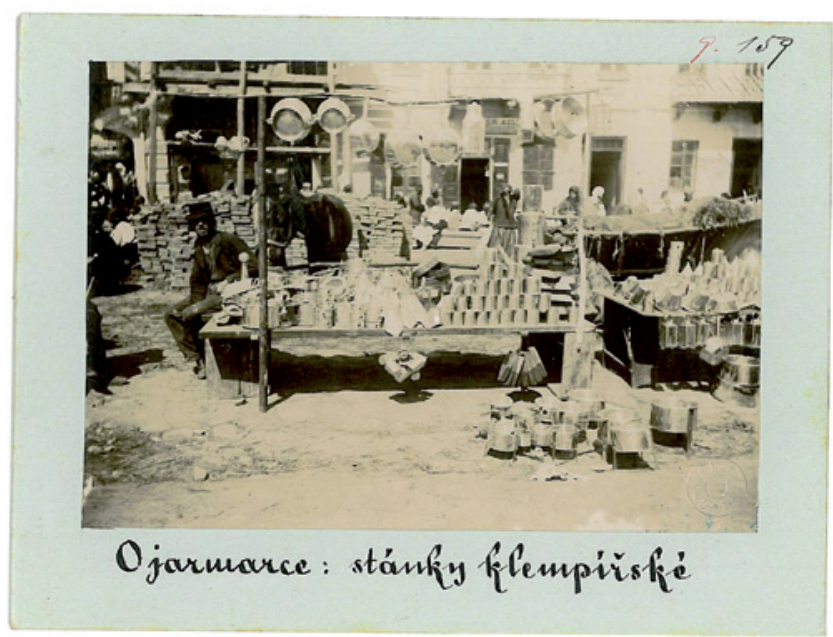

Obr. 8. "O jarmarce: stánky klempiŕské", východní Halič, 90. léta 19. století, NM - NpM, sbírka historických fotografí, sig. 9.0159. Foto František Řehoř.

ného materiálu naznačuje plánovaný rozsah. Je evidentní, že Řehoř již měl v této době s pořizováním fotografií jisté zkušenosti: „Poř́dil jsem si opět (vinou honoráre ze Světozoru) několik tuctů fotogr. plotýnek, tak, že letošní sběr, pokud se týče fotografii, dosáhne okolo 300 kusủ. Prosím tedy o 300 papírů, týž, jako predešlý tj. Aristo-papier v rozměru $9 \times 12$ cm. V jedné obálce bývá 25 kusư, tedy 12 obálek. Na každé obálce jest vytištěno Aristo-papier. Ten predešlý byl velmi dobrý; jedna obálka s 25 kusy stojí tuším 85 kr. ve Lvové, v Praze jistě méně. Co by papíru přebylo, upotřebí se jindy. Tolik podobizen, kolik papírù obdržim a již obdržel, vždy odvedu. Někdy se otisk neudá, někdy musím posílati sem tam obrázek na památku. Zrovna tak jako s fotogr. plotýnkami, an časem musím fotografovati, co s národopisem nemá nic společného. K papíru bude potreba 300 kartonů téže velikosti jako predešle. Miru račte dáti dle jedné z letošnich fotografí, aby celá sbírka méla stejný formát. Asi 100 by mohlo býti růžové barvy (na Huculy), ostatní jako dávnější (těch něco ještě mám). Kdo kartony nařeže at’ to činí ostrým nástrojem. Na druhou stranu každého kartonu umistím text inkoustem. Druhé práni týká se Eikonogen-patrone, které se prodávaji na balićky, v jednom 10 patron. Ty potřbuji $k$ vyvolání něco tuctů obrázki̊v, jež mnè zbyly a ještě přibudou. Konečně třeti: račte lask. dáti připraviti tekutinu tzv. Goldbud-recepis na ni jsem přiložil do předešlého listu. Této tekutiny bude litr a nejlépe by bylo poslati ji ve dvou $1 / 2$ litrových lahvích, arci ze silného skla a dokonale vyčištěných. Lahve, jež prodávají v lekárně, mají sklo tenké; a jen obaliti ještě slamou atd. Aristopapier, Eikonoge-patronen a onu

37 František ŘEHOŘ, „Obrázky z Pokuči““, Světozor, 1881, roč. 15, č. 36, s. 425, 434-435. František ŘEHOŘ, „Huculští novomanželé z Berhometa“, Světozor, 1881, roč. 15, č. 45, s. 533, 542. František ŘEHOŘ, „Unižská děvčata ve svátečním obleku“, Světozor, 1882, roč. 16, č. 7, s. 73, 82. František ŘEHOŘ, „Pokutští hudebníci“, Světozor, 1882, roč. 16, č. 15, s. 169, 178. Dle poznámky na fotografiích 40.0123, 40.0125 a 40.0126 (NM - NpM, sbírka historických fotografií).

38 Titulní obrázek Světozoru, 1882, roč. 16, č. 7 publikovaný pod názvem „Děvčata z Uniže v Pokučí“ ukazuje značnou míru umělecké licence. Obrázek znázorňuje tři postavy, u původní fotografie z ateliéru J. Dutkiewicze prostřední postava chybí, viz 40.0027 (NpM, sbírka historických fotografíi), též Pk 106, 88b, ÖNb [cit. 31.5.2021]. Dostupné z: https://onb.wg.picturemaxx.com. K tématu publikování také: Nad’a VALÁŠKOVÁ, František Řehoř (1857-1899) a jeho etnografická činnost, s. 56; Petr KALETA, Cesta do Haliče, s. 139.

39 Pasáž o molech v textilních sbírkách z dopisu Josefy Náprstkové z 18. 11. 1889: „, Proto znovu prosíme, jste ráčil co možná vždy na tyto pokušitele pamatovat, neb když ne za 10 let, tak ale jistě s letma se předce předměty ty úplně zničí; a tu když bude fotografie neb obrázek v kroji, to dostačí; neb neračte znát jakou bolest mně podobná nehoda připravi [...]. "Památník národního písemnictví, fond Řehoř František, Korespondence přijatá - Josefa Náprstková, karton 4.

40 Nad’a VALÁŠKOVÁ, František Řehoř (1857-1899) a jeho etnografická činnost, s. 56. 

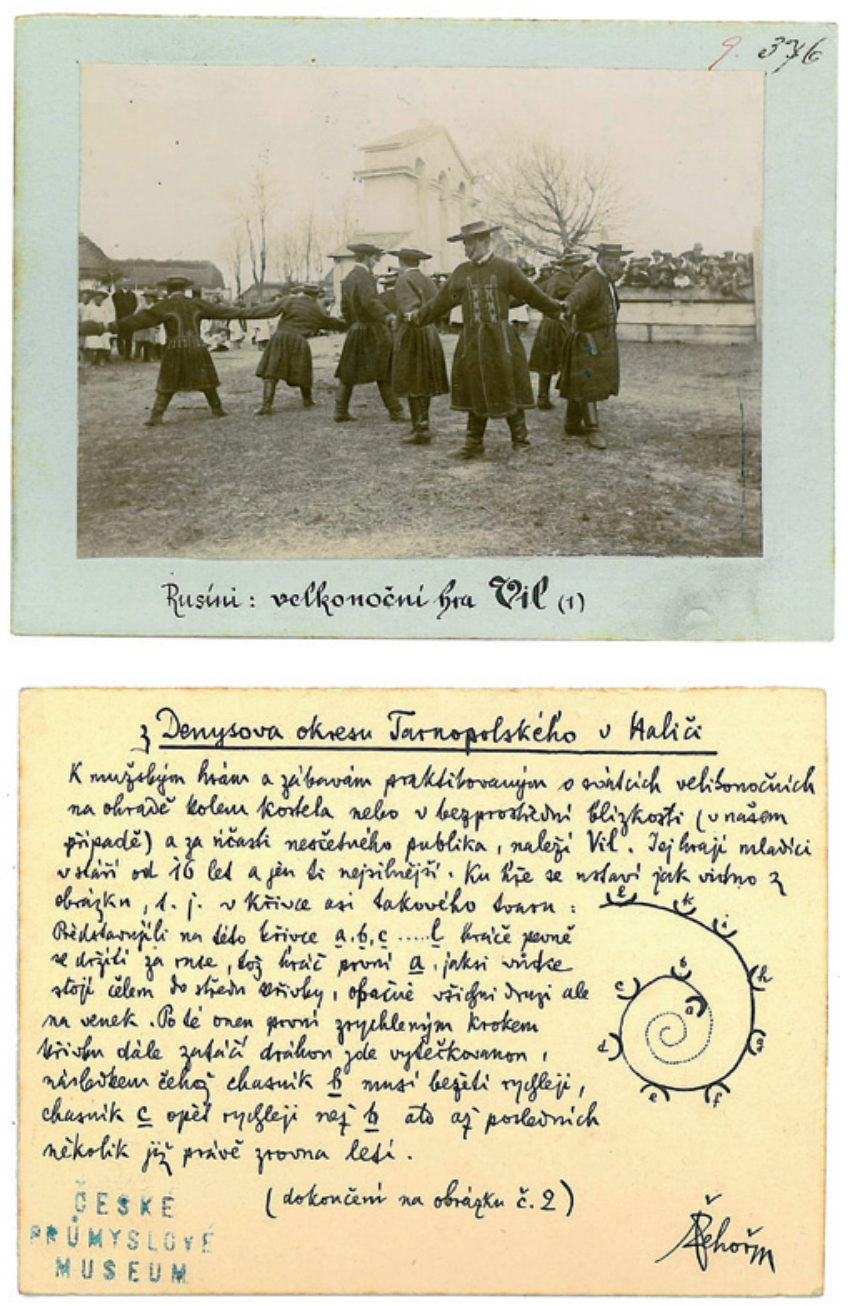

Obr. 9. „Rusíni: velikonoční hra vil. (1.)“, východní Halič, 90. léta 19. století, NM- NpM, sbírka historických fotografí, sig. 9.0376. Foto František Řehoř.

tekutinu nejlépe jest opatřiti ve skladě s fotografickými potřebami např. u Kreidla, ale i lekárny bývaji tím zásobeny. "41 Podíváme-li se na tuto část sbírky uloženou v NpM, vidíme, že většinu $\mathrm{z}$ výše popisovaných záměrů uskutečnil.

V závěru 19. století byl pro sbírku sestaven inventární seznam. Vzhledem k pořadí fotografí je pravděpodobné, že byly tematicky utř́íděny a opatřeny signaturou právě $\mathrm{v}$ tomto období a jejich řazení tak nenaznačuje chronologický vývoj sbírky ${ }^{42}$ a nemusí vždy souviset ani s Řehořovou představou o jejím uspořádání. Tuto skutečnost naznačují nejen rozdíly v trrídění negativư ${ }^{43}$ ale také zmiňovaná Huculská sbírka, ${ }^{44}$ která se v souboru nenachází jako celek, ale jejíž části jsou rozptýleny.

Některé negativy Řehoř zpracoval př́mo $v$ terénu, jak naznačil $\mathrm{v}$ jedné $\mathrm{z}$ poznámek na zadní straně fotografie:
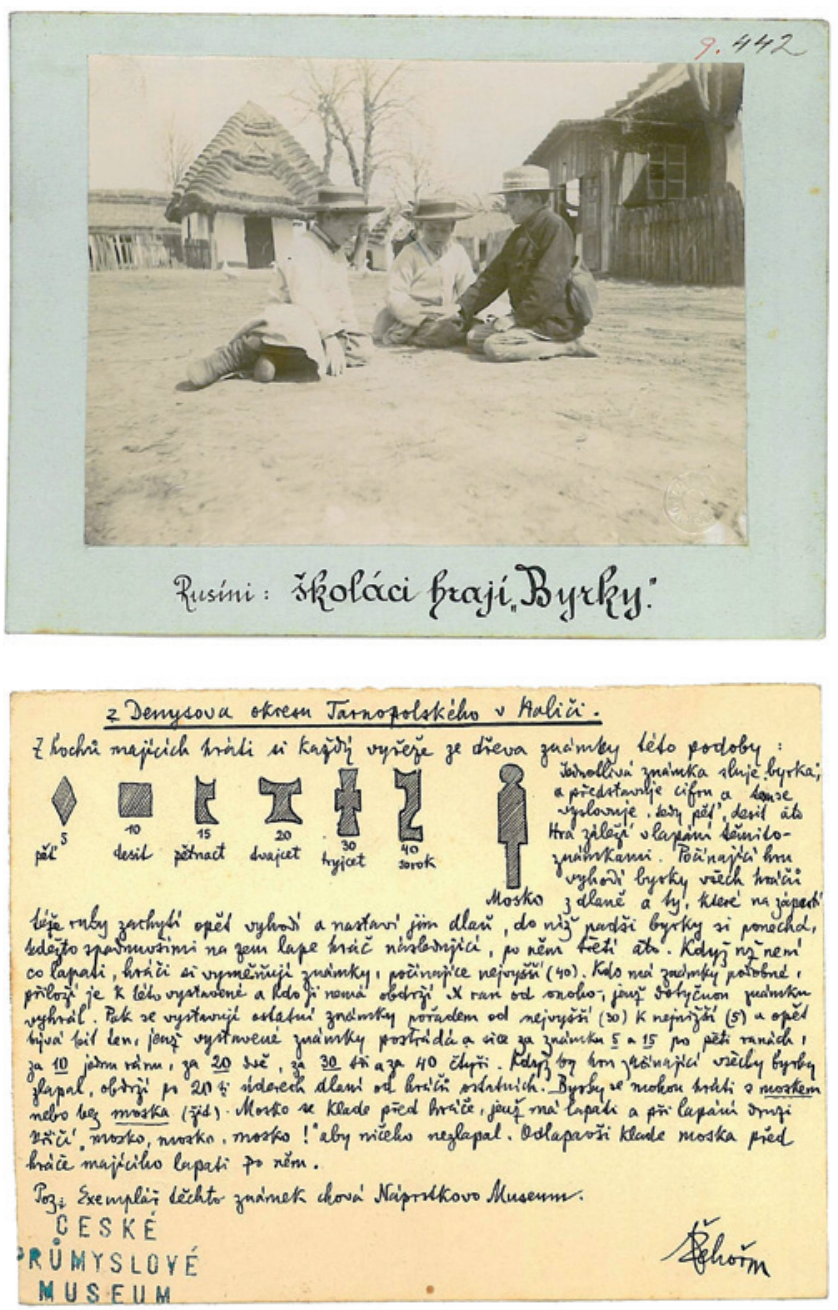

Obr. 10. „Rusíni: školáci hrají ,byrky“ “, východní Halič, 90. léta 19. století, NM - NpM, sbírka historických fotografíi, sig. 9.0442. Foto František Řehoř.

„,V pozadí jest budova, slehši se během desitek let, že nyni její stěna jest pouze metr vysoká. Za mého pobytu v Tyškovcich [...] upravili v ni pro mne a prof. Šucheviče lůžka. Vni dále jsem na negativech vyvolal všechny přitomné obrázky z Tyškovec a prì tom sobě hlavu o strop otloukal. "45

Při fotografování se Řehoř potýkal s různými technickými omezeními, jejichž důsledky je možné pozorovat jak na negativech, tak na fotografích. ${ }^{46}$ Při porovnání negativů s pozitivy se ukazuje, že většina vad patrných na vyvolaných snímcích byla př́tomna již na negativu. Tyto nedostatky Řehoř řešil retuší, která se $\mathrm{v}$ různém rozsahu dochovala téměr na třetině fotografií. ${ }^{47}$ Ve sbírce využival retuše výhradně ke kompenzaci nedostatků. Ztmavováním světlých míst tuší dodával problematickým nevýrazným místům potřebný kontrast. ${ }^{48}$

${ }_{41}$ NM- NpM, Archiv Náprstkova muzea, fond V. Náprstek, korespondence F. Řehoře, karton 43, č. 55.

42 Většina fotografí ve fondu není F. Řehořem datována. Výjimku tvoří fotografie 9.0288 z roku 1892; dále 9.0194, 9.0195, 9.0197, 9.0354, 9.0467 a 9.0486 z roku 1893. Poslední z datovaných fotografí́ 9.0552 pochází z roku 1894. U několika dalších snímků je pak možné určit jejich vznik před rokem 1894 vzhledem k publikování v témže roce. Uvedené informace jsou v souladu s předpokladem N. Valáškové.

43 Dle Řehořových seznamů.

44 Snadno rozpoznatelná nejen dle výše zmíněných růžových kartonů, ale také dle nápisu „Haličtí Huculové“ na zadní straně kartonu. Část fotografické sbírky věnované Huculům čítá 69 kusů.

45 Národní muzeum - Náprstkovo muzeum, sbírka historických fotografí́, sig. 9.0210.

46 O Řehořových nesnázích s fotoaparátem zapůjčeným od prof. Šuchevyče podrobněji Petr KALETA, Cesta do Haliče, s. 143.

47 U některých exemplářủ je obtížné rozpoznat, zda se jedná o retuši, nebo znečištění.

48 Míra užití retuše se různí - od drobných zásahů, jakým je zvýraznění očí, po výrazné zásahy, kde jsou dokreslovány části postav. Řehoř tak pravděpodobně usiloval o využitelnost co možná největšího množství pořízených snímků. Např. 9.0065, 9.0075, 9.0077, 9.0117. 
U vyvolaných fotografií lze vysledovat různý rozsah ořezu, který pravděpodobně vycházel ze snahy omezit množství technických vad na snímku. Mohlo se jednat také o úpravu kompozice. ${ }^{49}$ Necitlivé zásahy, jako je plošná retuše pozadí častá u soudobých fotografií s etnografickou tematikou, Řehoř nevyužíval. ${ }^{50} \mathrm{Na}$ jednotlivých fotografiích nalezneme také rozdíly v kvalitě retuše. Je pravděpodobné, že v průběhu práce Řehořova ruka získávala na jistotě. Některé neumělé zásahy mohou být také zvýrazněny v důsledku blednutí fotografií.

Velkou část z Rehořovy tvorby lze považovat za fotografii dokumentární. Pro počátky tohoto odvětví byly typické četné zásahy, kdy autoři v některých prrípadech zakomponovali do focené scény $v$ té době již odložené předměty a oděvy. ${ }^{51}$ Nabízí se otázka, jakou měrou vstupoval do podoby svých fotografií F. Řehoř. V jedné z poznámek píše: ,, Takto ze směru [čeledín] zabočil po mém přání, aby se fotografie zdařila. “52 Moment překvapení naznačuje: „Právě před stožkem zastavil hospodár jdoucí ze stodoly (vlevo), patrně zaražen mým objevením se v jeho vratech. " ${ }^{53} \mathrm{Z}$ Řehořových fotografií se zdá, že míra stylizace a zásahů do podoby celkové koncepce snímku byla $v$ jeho případě spíše menší. V souboru nalezneme skupinové fotografie či fotografie jednotlivců, kteří na přání fotografa zapózovali. Převládají ale snímky, kde autor usiloval o co možná nejvěrnější zachycení každodenního života. Tyto záběry vznikaly díky jeho pozorovacímu talentu, dobré znalosti místních podmínek a možnosti pobývat dostatečně dlouho $v$ terénu.

Specifikem Řehořovy tvorby je autenticita, s jakou se nevyhýbal ani dokumentaci chudoby a tvrdých životních podmínek ve východní Haliči. Jeho tvorba není zatížena jevy typickými pro etnografickou fotografii $\mathrm{v}$ závěru 19. století, která byla využívána mimo jiné jako nástroj prezentace národní svébytnosti. Řehoř mohl v Haliči snáze přijmout úlohu nezaujatého pozorovatele. Svým citem pro detail, ale i pro souvislosti, co do obsahu fotografie, nikoliv výtvarného pojetí a technické úrovně, dosahuje výsledků, za něž je v českém kontextu oceňován Erwin Raup, který nafotil svůj cyklus na jihovýchodní Moravě o více než deset let později. ${ }^{54}$

\section{Fotografická sbírka jako etnografický pramen}

Vyvolané fotografie F. Řehoř lepil na kartony o rozměrech cca $10 \times 13 \mathrm{~cm}$ a na přední i zadní straně je opatřil doprovodným textem, jak avizoval ve výše citovaném dopisu. Záměr takto okomentovat každý snímek badatel splnil pouze částečně, a to v 270 prípadech. S popiskem se setkáváme ve dvou variantách: s krátkým (někdy vtipným) titulkem a lokalitou na přední straně ${ }^{55}$ a v delší variantě, která pokračuje na zadní straně. ${ }^{56}$

Řehoř v této části dokumentace vykresluje obsah popisované fotografie a v některých případech vysvětluje okolnosti jejího pořízení. Nalezneme drobné př́iběhy dokreslující podobu každodenního života $\mathrm{v}$ míře, která je pro dobové záznamy poměrně neobvyklá, nebot' pro svou zdánlivou nepodstatnost stála mimo „hledáček “ badatelü ${ }^{57}$. F. Řehoř zde prokazuje svůj pozorovací talent. Všímá si drobných detailů každodenní těžké práce. Uved'me několik příkladů: „Pro načatou vstavku ${ }^{58}$ sáhne do záňadř́ a pokračuje v ní na dvore (na obrázku), na poli, na trhu a j. Odkazuji na pendant ,Jedoucí s hnojem vyšivá: ${ }^{59}$ "Hospodyně na plotě hražení pro hnojiště rozvěšuje kožichy na čerstvé povětř́i, její muž je na cestě do stodoly a děti sedice na zápraží, ohryzují pečené klasy kukuřičné. “60 „Hospodář podle zabodnutých vidlí si veze otýpečku slámy, na kterou sedá při návratu s prázdným vozem, aby se nezamazal. “61 „Konec copu si v práci zatkávají za tkanici zástěry v křrži, aby neprekážel. "62

Cennou informací je také zachycení soudobých lidových názvů. Popisy tak často zahrnují názvy fotografovaných zařízení a jejich součástí či výrobních postupů. Řada fotografií je rovněž doplněna plánky či schematickými nákresy.

V několika případech narazíme na poznámky osobního charakteru: ,Po nemoci r. 1893 v záŕi diky laskavosti rusínského faráre z Ivanovec p. [...] Levického zotavoval jsem se asi 14 dnů na této faře. "63

Dle obsahu lze Řehořovy snímky rozčlenit do několika tematických celků, jak již nastínili N. Valášková a P. Kaleta. ${ }^{64}$ Jsou jimi sídla (architektura světská i církevní, venkovská, městská, stavby technického charakteru a hřbitovy),

49 K tomu také Petr KALETA, Cesta do Haliče, s. 143. V ojedinělých př́ípadech pak přináší negativ rozšiřující informaci, jako v případě fotografie 9.0225, kam se díky ořezu $\mathrm{v}$ důsledku vad negativu nedostalo děvčátko přihlížející práci se senem.

50 Výjimku tvoří fotografie 9.0479. Pozadí bylo rovněž retušováno u některých fotografií publikovaných v časopisech. František ŘEHOŘ, Z cest po Haličské Rusi. Z Rohatyna do Kołomyje, Světozor, 1893-1894, roč. 28, č. 39, s. 464. Helena BERÁNKOVÁ, Souvislosti etnografické fotografie, in: Jiří MITÁČEK - Luděk GALUŠKA (eds.), Stopy minulosti: věda v Moravském zemském muzeu na prahu třetího tisíciletí, Brno 2011 , s.465. Národní muzeum - Náprstkovo muzeum, sbírka historických fotografí́, signatura 9.0225. Archiv Národního muzea, Archiv Národního muzea, OAE $n$ II 17.

51 Jiří PÁTEK, Fotografie, etnografie, tradiční kultura - průniky a inspirace, Národopisná revue, 2003, roč. 13, č. 4, s. 183; Helena BERÁNKOVÁ, Souvislosti etnografické fotografie, s. 473.

52 NM - NpM, sbírka historických fotografí, sig. 9.0187.

53 Tamtéž, sig. 9.0032.

54 Helena BERÁNKOVÁ, Souvislosti etnografické fotografie, s. 470; Pavel SCHEUFLER, Osobnost fotografie v českých zemích do roku 1918, s. 297.

55 Kratší varianta může být doplněna o upřesnění lokality na zadní straně.

56 Jednotlivé popisy se liší délkou. Kromě kratších popisů čítajících několik vět nejsou výjimkou ani exempláře, u kterých byl prostor na zadní straně kartonu zcela využit.

57 Informace v textu naznačují, že fotografování doprovázel rozhovor s aktéry snímku.

58 Ozdobná vložka všitá do textilu.

59 Řehoř zde odkazuje na fotografii dívky, která vyšívá i v situaci, kdy veze vůz naloženým hnojem. Fotografie ve sbírkách NpM je bohužel výrazně poškozena. Národní muzeum - Náprstkovo muzeum, sbírka historických fotografíi, signatura 9.0329, 9.0335, ANM EAO n XII_164.

${ }_{60} \mathrm{NM}$ - NpM, sbírka historických fotografíi, sig. 9.0028.

61 Tamtéž, sig. 9.0188.

62 Tamtéž, sig. 9.0261.

63 Tamtéž, sig. 9.0039, podobně u 9.0040.

${ }^{64}$ Nad’a VALÁŠKOVÁ, František Řehoř (1857-1899) a jeho etnografická činnost, s. 56. Petr KALETA, Cesta do Haliče, s. 140-143. 


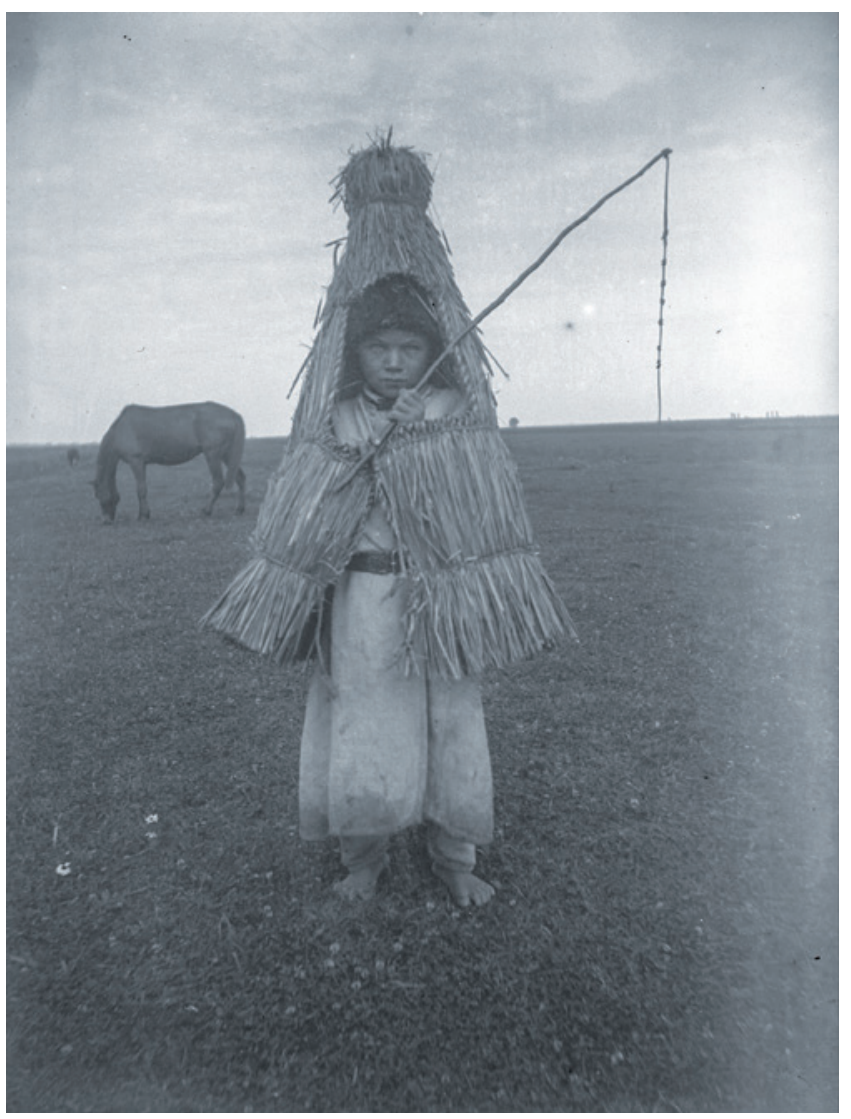

Obr. 11. „Pasák v slaměné rohoži v Berežnici Královské", Berežnycja, východní Halič, 90. léta 19. století, František Řehoř, ANM, EAO n IX_124.

zaměstnání (polní práce, domácí práce a řemesla), festivity (církevní svátky, výroční a rodinná obřadnost). Jako samostatný celek oba autoři shodně, zřejmě pro jeho široké zastoupení, uvádějí trhy. Valášková pak řadí mezi významné celky oděv. V souboru je zároveň možné odhalit řadu podtémat, s kterými se setkáváme např́íc kategoriemi. Jednou $\mathrm{z}$ nich je odpočinek ${ }^{65}$ či svět dětí. S tématem festivit se prolíná téma hry a tance. Materiál dokumentuje tradiční rozdělení mužských a ženských rolí. Objevují se rovněž témata zastoupená na fotografii pouze okrajově či asociace, které s fotografovaným obsahem vzdáleně souvisejí.

Řadě témat se Řehoř věnoval opakovaně a sesbíral materiál z různých míst. U některých činností, at' už se jednalo o zemědělské práce, výrobu, či hry a tance, zdokumentoval jednotlivé fáze procesu. O následném pečlivém zpracování materiálů svědčí badatelovy odkazy, upomínající na související fotografický materiál v rámci sbírky.

Přihlédneme-li k dokumentaci na zadních stranách snímků, odhalíme skutečnou šíri témat, kterou nám F. Řehoř na svých fotografiích přibližuje. Každé téma pak autor propojuje s praktickými stránkami každodenního života lokální komunity. U fotografí církevních staveb se dozvídáme nejen informace spojené s charakterem budovy či vírou, ale také

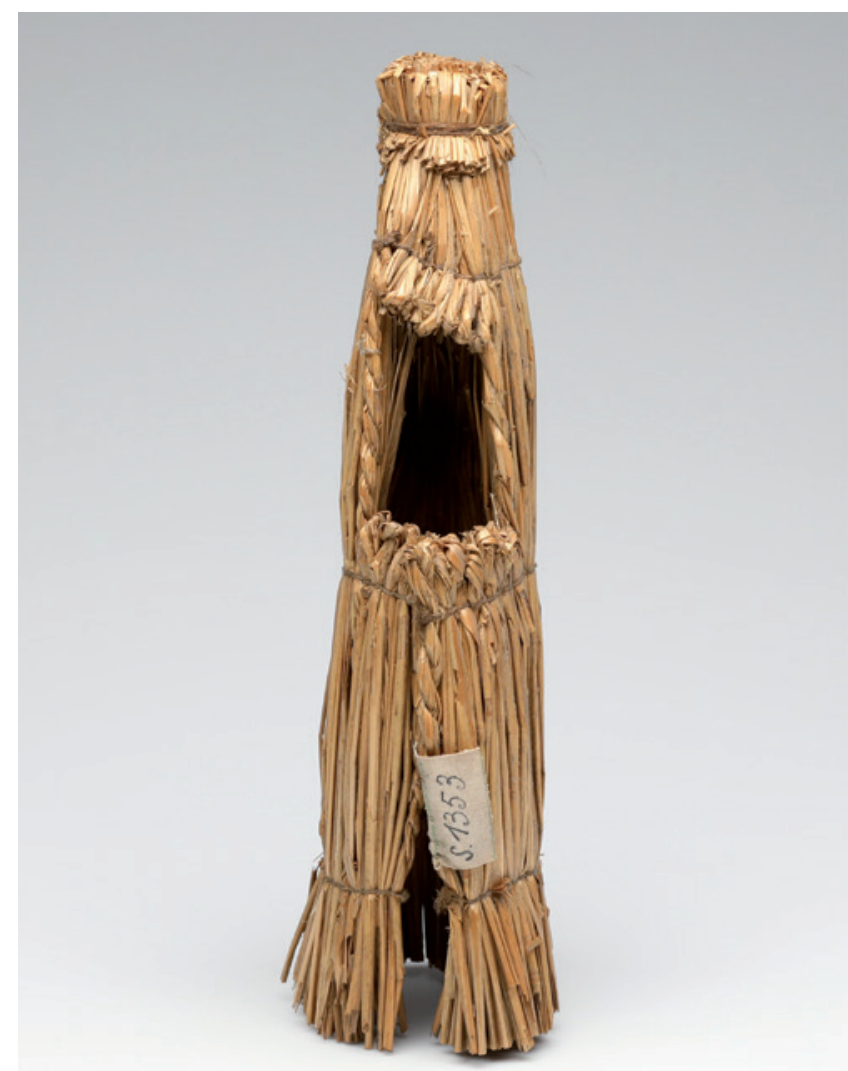

Obr. 12. Model "rohože“ ze sbírky Františka Řehoře, východní Halič, poslední čtvrtina 19. století, NM H4-NS-1353. Foto Olga Tlapáková.

jakým způsobem se obec vypořádává s nákladnou stavbou po praktické a finanční stránce. Na fotografii cerkve v Denysově Řehoř např́klad zmiňuje důvod odkladu její vnitřní výmalby: , [...] aby se osada v jediném roce finančně nevysílila “ ${ }^{66}$ Dočítáme se také, že „,kdykoliv se cerkov buduje, obec dřive musí napáliti cihel ". .77

Řehoř fotoaparátem zachytil venkovská i městská obydlí různých společenských vrstev. Dokumentoval také významné správní budovy. Fotografie doprovází informace o funkci staveb i společenském postavení majitele. Kromě vnějšího členění hospodářského zázemí je $\mathrm{v}$ několika případech doplněn popis vnitřního rozvržení domu, ačkoliv interiérové fotografie nejsou v souboru téměr zastoupeny. I zde jsou v popisu akcentovány každodenní činnosti. ${ }^{68}$

Texty doprovázející fotografie trhů obvykle přinášejí dvě roviny informací. Vedle popisu fungování trhů, textů o aktivitách prodejců a o jejich vztazích se zákazníky skýtá cenné informace popis vystaveného zboží zahrnující vysvětlení, pro jaké účely je užíváno. ${ }^{69}$

Tématu odívání se Řehoř kromě aranžovaných fotografí jednotlivců i skupin věnuje na řadě žánrových snímkủ z každodenního života. ${ }^{70} \mathrm{Na}$ fotografii 9.0311 je žena nesoucí na ramenou dítě: ,Putuje bosa a že by $v$ sparný srpnový den

65 Petr KALETA, Cesta do Haliče, s. 142

${ }^{66} \mathrm{NM}$ - NpM, sbírka historických fotografí́, sig. 9.0006.

67 Tamtéž.

68 Např. tamtéž, sig. 9.0014-9.0018, 9.0229, 9.0032, 9.0033.

69 Např. tamtéž, sig. 9.0136, 9.0137, 9.0167.

70 Informuje o funkčních vlastnostech i o praktickém užití. 


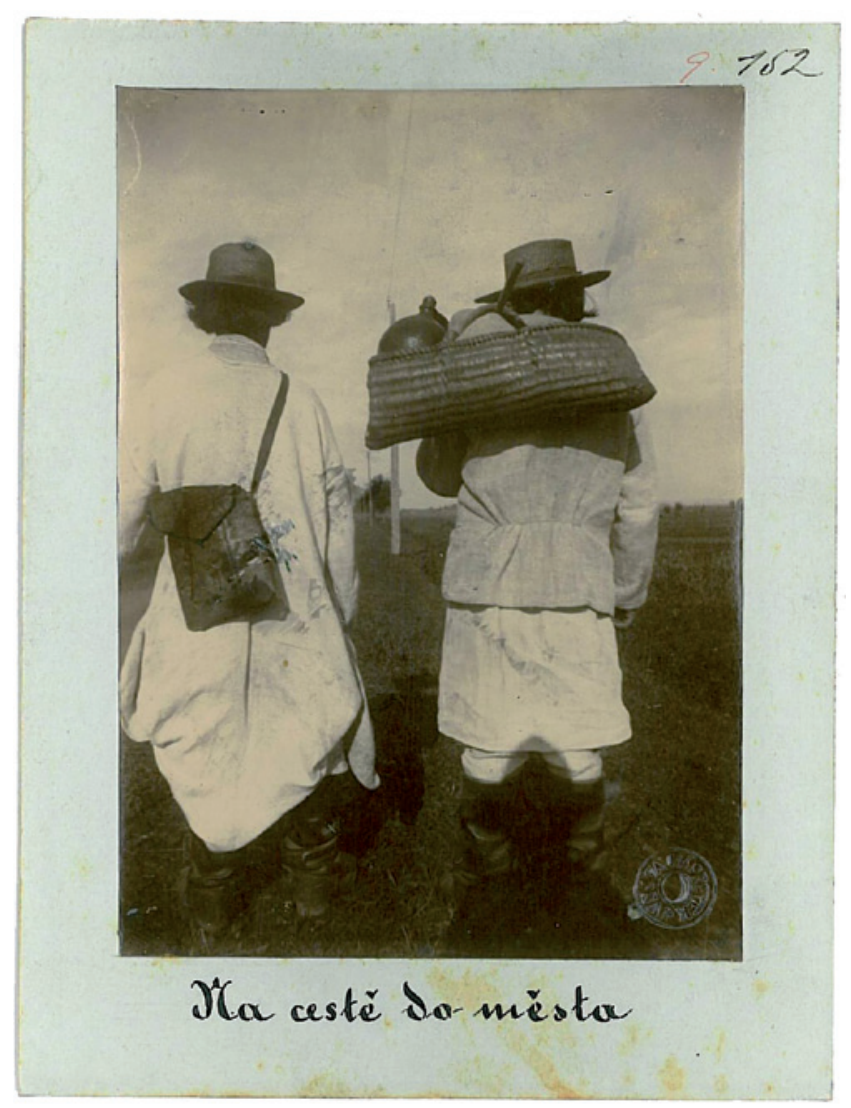

Obr. 13. "Na cestě do města“, východní Halič, 90. léta 19. století, NM - NpM, sbírka historických fotografí, sig. 9.0152. Foto František Řehoř.

kožich hřál, oblékla jej obrácený, jednak [...] kůže chladí, jednak nepopraská od slunce. "1

Život dětí, chlapců i děvčat různých věkových skupin ${ }^{72}$, patří mezi motivy, které prostupují Řehořovy fotografie napříc tématy. $\mathrm{V}$ jeho tvorbě nalezneme množství činností, v nichž jsou děti hlavními aktéry. Sledujeme je při polních pracích, pomoci v domácnosti, péči o sourozence či hrách, at' už se jedná o hry s jasně stanovenými pravidly, nebo zábavu, jakou je chůze v bahně. Na snímku s názvem „Děti na mne zevlujici'“ "Rehoř píše: „Na svých pochůzkách s fotografickým př́strojem dèti se mne zprvu bály, utikajic přede mnou. Teprve když si mne okoukaly a jejich bojácnost jsem jim rozmluvil, vytrvale již sledovaly každé mé hnutí. [...] Aby na mé fotografováni měly památku, učinil jsem jednou obrat a namiřil prístroj na né. "“3

\section{Závěr}

Fotografická sbírka Františka Řehoře představuje významný zdroj informací, který svým obsahem přesahuje př́nos fotografie jako ikonografického pramene. Jedná se o výsledek precizní dlouhodobé badatelské činnosti se záměrem maximalizovat výpovědní hodnotu pořízeného materiálu. Toho se Řehoř snažil docílit pečlivým popisem snímků s odkazy na různé souvislosti $\mathrm{s}$ dalšími fotografiemi. Takto pečlivá dokumentace je pro závěr 19. století nadstandardní.

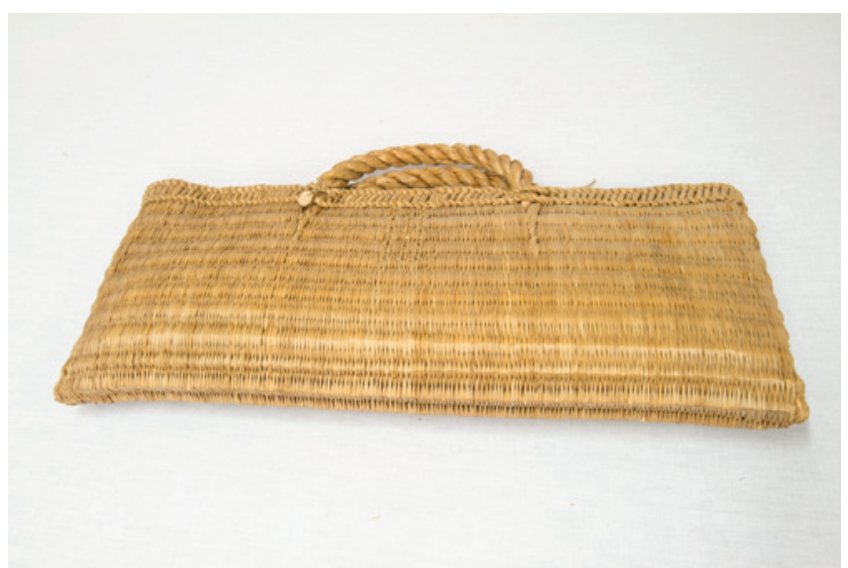

Obr. 14. Pletená taška z orobince ze sbírky Františka Řehoře, východní Halič, poslední čtvrtina 19. století, NM H4-NS-1338. Foto Olga Tlapáková.

Řehořova snaha o co nejucelenější obraz života místních komunit umožňuje také tematické propojení sbírkové a fotodokumentační činnosti. Fotografie často zachycují předměty (at’ již při výrobě, ve fázi prodeje či při užití spotřebiteli) Řehořem v minulosti sesbírané. Snímky tak přinášejí ne zcela obvyklé rozšíření muzejní dokumentace o cenný kontext.

Budoucí zpracování negativů z fondu PNP vzhledem $\mathrm{k}$ charakteru sbírky negativů v OAE může odhalit další dosud neznámé snímky F. Řehoře, zároveň se nabízí možnost, že se budou mezi dosud nezpracovanými negativy nacházet ty, jejichž pozitivy jsou výrazněji poškozeny.

Řehořova fotodokumentace představuje důležitý zdroj informací pro studium dobových reálií. Je cennou sondou do života venkovského obyvatelstva východní Haliče v závěru 19. století a součástí komplexních výzkumných aktivit badatele.

\section{Prameny}

Národní muzeum - Náprstkovo muzeum, sbírka historických fotografií, sig. 9.0001-9.0553

Národní muzeum - Náprstkovo muzeum, sbírka historických fotografí, sig. 40.0001-40.0137a

Národní muzeum - Náprstkovo muzeum, Archiv Náprstkova muzea, fond V. Náprstek, korespondence F. Řehoře karton 43 , č. 55.

Památník národního písemnictví, fond Řehoř František, Korespondence př́ijatá - Josefa Náprstková, karton 4.

František ŘEHOŘ, Huculští novomanželé z Berhometa, Světozor, 1881, roč. 15 , č. 45, s. 533, 542.

František ŘEHOŘ, Obrázky z Pokučí, Světozor, 1881, roč. 15, č. 36, s. 425, 434-435.

František ŘEHOŘ, Pokutští hudebníci, Světozor, 1882, roč. 16, č. 15 , s. 169 , s. 178.

František ŘEHOŘ, Unižská děvčata ve svátečním obleku, Světozor, 1882, roč. 16 , č. 7 , s. $73,82$.

František ŘEHOŘ, Z cest po Haličské Rusi. Z Rohatyna do Kołomyje, Světozor, 1894, č. 39, s. 464.

71 Tamtéž, sig. 9.0311.

72 Např. tamtéž, sig. 9.0330, 9.0340, 9.0442, 9.0461, 9.0462, 9.466 a další.

73 Tamtéž, sig. 9.0459. 


\section{Literatura}

Helena BERÁNKOVÁ, Souvislosti etnografické fotografie, in: Jiří MITÁČEK - Luděk GALUŠKA (eds.), Stopy minulosti: věda v Moravském zemském muzeu na prahu třetího tisíciletí, Brno 2011, s. 465-477.

Olena FEDORCHUK - Oleh BOLYUK - Jan POHUNEK Nad'a VALÁŠKOVÁ, Lidová kultura Ukrajinců rakousko-uherské monarchie v etnografické sbírce Františka Řehoře z 80. a 90. let 19. století, Český lid, 2020, roč. 107, s. 71-92.

Jiří HORÁK, Příspěvek k dějinám vzájemných vztahů česko-ukrajinských. Dílo Františka Řehoře, Český lid, 1954, roč. 41, č. 6, s. 254-258.

Stella HRYNIUK - Jeffrey PICKNICKY, The Land they left behind, Toronto 1995.

Petr KALETA, Cesta do Haliče. František Řehoř a poznání života východní Haliče ve druhé polovině 19. století, Olomouc 2004.

Petr KALETA, Fotodokumentace a sběratelství v díle Františka Řehoře, Slovenský národopis, 2003, roč. 51, č. 2, s. 235-243.

Helena MEDŘICKÁ - Daniela ZÁVESKÁ - Kristýna BLECHOVÁ - Oleh BOLYUK - Olena FEDORCHUK, Stará Ukrajina Františka Řehoře, informační brožura k výstavě, Praha 2019.
Michal MOLNÁR, Франтішек Ржегорж - великий друг українского народу, Дукля, 195б, № 3, s. 121-146.

Jiří PÁTEK, Fotografie, etnografie, tradiční kultura - průniky a inspirace, Národopisná revue, 2003, č. 4, s. 183190.

Pavel SCHEUFLER, Osobnost fotografie v českých zemích do roku 1918, Praha 2013.

Nad'a VALÁŠKOVÁ, František Řehoř (1857-1899) a jeho etnografická činnost. (S ukázkami článků F. Řehoře z Haliče), Praha 1999.

Milena SECKÁ, František Řehoř and his Collection of Photographs from Halič in the Náprstek Museum (on the $100^{\text {th }}$ anniversary of his birth), Annals of the Náprstek Museum, 1999, roč. 20, CD-ROM.

Nad'a VALÁŠKOVÁ, František Řehoř a jeho fotografická sbírka z Haliče, Ukrajinský žurnál, české vydání, 2007, roč. 2, č. 2, s. 32-34.

\section{Internetové zdroje}

Archivní VadeMeCum NM [cit. 31.5.2021] Dostupné z: http://vademecum.nm.cz/

Österreichische Nationalbibliothek [cit. 31.5.2021]. Dotupné $\mathrm{z}$ : https://onb.wg.picturemaxx.com 